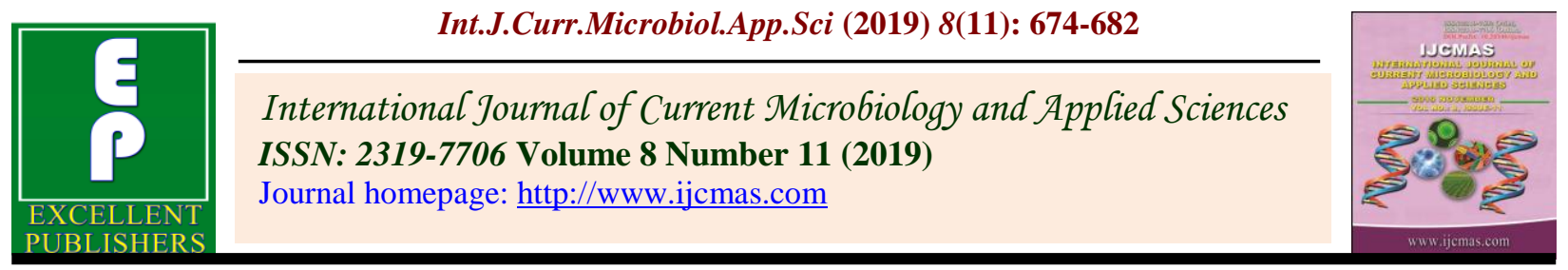

Original Research Article

https://doi.org/10.20546/ijcmas.2019.811.081

\title{
Growth Performance of Silkworm Cocoon Production in Karnataka, India
}

\author{
G.N. Anil Kumar ${ }^{1}$, B.S. Reddy $^{2 *}$, S.B. Goudappa ${ }^{3}$, \\ G.M. Hiremath ${ }^{1}$ and Suresh S. Patil ${ }^{1}$ \\ ${ }^{1}$ Department of Agricultural Economics, UAS, Raichur, 584104, India \\ ${ }^{2}$ Department of Agricultural Economics, College of Agriculture, Kalaburagi, 585101, India \\ ${ }^{3}$ Department of Agricultural Extension Education, UAS, Raichur, 584104, India \\ *Corresponding author
}

\begin{abstract}
Keywords
Cocoon, Disease

free layings,

Growth,

Productivity,

Silkworm

Article Info

Accepted:

07 October 2019

Available Online:

10 November 2019 year. The study was conducted to examine the growth in area under mulberry, production and productivity of mulberry silkworm cocoon in traditional and non-traditional areas of Karnataka. Secondary data was collected over the period of 20 years from 1998-99 to 2017-18. The study indicated that the growth in area under mulberry was declined in Karnataka as well as India whereas, growth in production was positive in India and negative in Karnataka due to positive growth in productivity both in Karnataka and India. The traditional districts have shown negative growth in area $(-1.77 \%)$ but positive growth in productivity $(1.36 \%)$ resulted marginal decline in production $(-0.07 \%)$. Similarly, the growth in nontraditional districts of mulberry cultivation indicated negative growth rate in both area $(-1.48 \%)$ and production $(-0.56 \%)$ while it was positive in case of productivity $(1.71 \%)$ of silkworm cocoon.
\end{abstract}

\section{A B S T R A C T}

Sericulture is one of the important enterprises undertaken by farmers in Karnataka which is giving employment to family labour throughout the

\section{Introduction}

'Sericulture' is an art and science of rearing silkworms to produce cocoons and silk. It includes rearing of silkworms, growing of mulberry, reeling of silk thread from cocoons, weaving the silk yarn and further processing to produce the silk fabric. Sericulture is an important means for the socio-economic development of the rural sector. It is highly labour intensive, profit oriented and low input indoor activity that gives frequent periodicity of economic returns. It is also well suited for the women folk of rural sector. India has unique distinction of being the only country in the world which produces all the known 
commercial varieties of silk-mulberry viz. tropical tasar, temperate tasar, eri and muga. India occupies a predominant position in the world and it is the second largest producer of silk after China.

Sericulture is labour intensive sector next to agriculture and provide sizeable employment to rural households. It is one of the important subsidiary activities taken up to augment household income in the country as well as in Karnataka.

Mulberry sericulture is practiced mainly in five states namely, Karnataka (42.24\%), Andhra Pradesh (30.71\%), West Bengal (11.67\%), Tamil Nadu (8.99\%) and Jammu and Kashmir (4.43\%), which collectively account for about 98 per cent of the total mulberry silk production in the country. It has a strong tradition and culture bound domestic market for silk. While the non-mulberry silks are produced in Jharkhand, Chhattisgarh, Orissa and north-eastern states.

The area under mulberry in Karnataka during 2017-18 accounted for 98,135 hectares with production of 66,833 tonnes of silk cocoons. Further, more than 1.26 lakh families are depending on sericulture and more than 7430 reeling families converts the cocoons in to silk yarn (9571 MT). In the past remunerative prices for silk cocoons gave an impetus and farmers who had uprooted mulberry also returned to replant mulberry many times.

Area under mulberry cultivation was increasing before the introduction of economic liberalization and this was facilitated by technological innovations provided by silk research institutions as well as incentives from the Government for expansion of sericulture. However, pursuance of economic liberalization and signing of WTO exposed sericulture industry in the country to international competition and opened the flood gates for import of cheap raw silk from china.
These impinge upon the demand for mulberry silk produced in the country and led to downward trend in cocoon and silk prices for domestic production and sericulture turned non-remunerative. This resulted in decline in the area under mulberry despite improvement in productivity (Srinivasan, 2006).

An analysis of the growth trends of area under mulberry as well as production and productivity of mulberry silk in the state as well in the country has been attempted which can provide a basis for future projection of future output. This paper therefore endeavours to analyze growth performance of silkworm cocoon production in Karnataka.

\section{Materials and Methods}

In the present study the time series data on mulberry area, production, and productivity of mulberry silkworm cocoon in India as well as Karnataka for the period from 1998-99 to 2017-18 were collected from Directorate of Economics and Statistics, Bangalore. In order to analyze the growth in of mulberry area, production and yield of mulberry silk, compound growth rate analysis was carried. The compound growth function was specified as follows:

The compound annual growth rates (CAGR) of area under mulberry, production of mulberry raw silk and productivity of silk are computed using the exponential growth function. The form of function used is

$\mathrm{Y}=\mathrm{a} b \mathrm{e}$

Where,

$\mathrm{Y}=$ Dependent variable for which growth rate is estimated

$\mathrm{a}=$ Intercept

$\mathrm{b}=$ Regression coefficient 
$\mathrm{t}=$ Time variable

$\mathrm{e}=$ Error term

Since the model being the multiplicative the function was transformed into additive model by simple logarithmic transformation as below:

$\ln \mathrm{Y}=\ln \mathrm{a}+\mathrm{t} \ln \mathrm{b}$

The per cent compound growth rate (CAGR) was derived using following formulae

CAGR $=($ Anti ln of $b-1) \times 100$

Growth rate is indicated by the value and sign of the 'b' coefficient. If coefficient is statistically significant and positive then growth of the estimated parameters over the years is positive or accelerating. If the value of ' $b$ ' coefficient is negative, it indicates that growth is negative or decelerating during the reference period.

\section{Results and Discussion}

Karnataka state is one of the important silkworm cocoon producing state in the country. The contribution of the state to country's silkworm cocoon production was 66,833 MT during 2017-18, however to understand in deep about contribution of region and district to state total production districts were classified into traditional and non-traditional districts. The districts which are cultivating mulberry more than 20 years were considered as traditional mulberry districts while others were considered nontraditional districts. The share of mulberry area and silkworm cocoon production to state's total is worked out and presented in Table 1. It is evident from the findings that traditional districts accounted major share $(87.72 \%)$ in the state total area under mulberry cultivation. Similarly production contributed to the extent of 91.21 per cent of Karnataka's silkworm cocoon production with an average yield of $642 \mathrm{~kg}$ per hectare. The nontraditional districts contributed 12.28 per cent and 8.79 per cent of state mulberry area and cocoon production respectively. It is important to note that the average cocoon yield realised was about $426 \mathrm{~kg}$ per hectare. Therefore, this will call for attentions of the agricultural scientists to find out the reason for large variation in the cocoon yield across the regions and districts of the state.

The growth in area under mulberry and production and productivity of silkworm cocoon was presented in Table 2. The growth in area $(-0.37 \%)$ was negative and nonsignificant while production $(4.07 \%)$ and productivity $(4.47 \%)$ were positive and significant at one per cent level in the country as a whole during study period. The decline in the area might be due to scarcity of labour, higher wage rate and low cocoon price. The positive growth in production and productivity might be due to the introduction of improved technologies by various institutions for silkworm rearing as well as introduction of high yielding silkworm breeds. The findings of the present study were in disagreement with the study conducted by Sharad and Shekar (2008) where mulberry cultivation has increased significantly at the rate of 0.25 per cent. However production and productivity of silkworm cocoon have increased significantly and findings of this study is in accordance with the findings of these authors.

The growth rate analysis in Karnataka state as a whole indicated that growth in area was observed to be $(-1.74 \%)$ negatively significant at five per cent level of significance. Similarly production has declined significantly at the rate of 0.08 per cent and significant at one per cent level. While, the productivity growth of silkworm cocoon was positive $(1.55 \%)$ and significant. The growth in area under mulberry 
indicated that the mulberry area and cocoon production were significantly declined mainly due to shortage of water, non-availability of labour, decline in soil fertility and shift in land use towards real estate in the traditional mulberry growing districts. However, growth in productivity of cocoons was positive mainly due to introduction of high yielding silkworm breeds. The findings of the present study are in agreement with the study conducted by Vishakanta (2018). It is important to note that, NEK region as whole revealed that growth in area and production were $(4.44 \%$ and $3.57 \%$ ) significant at one per cent level. The growth in silkworm cocoon production is mainly due to positive and significant growth in area under mulberry. The area under mulberry cultivation is increasing mainly due to profitability of this enterprise and suitability of land for cultivation of this crop as opined by farmers during survey. While, the growth in productivity of cocoon was negative $(-0.24 \%)$ and non-significant. For the purpose of analysing the growth in area under mulberry and silkworm cocoon production and its productivity, the districts were divided into traditional sericulture growing districts and non-traditional sericulture growing districts. The traditional mulberry growing areas owing to geographical and agro-climatic advantage tended to influence on area and production of mulberry in the state. The results of the compound growth rate analysis of area under mulberry and production and productivity of silkworm cocoon in the traditional and nontraditional area of the state is presented in Table 3.

\section{Traditional area}

It is clear from the table that growth rate in mulberry area $(-1.77 \%)$ and silkworm cocoon production $(-0.07 \%)$ during study period was declining significantly. The extent of decline in area was more in Chamarajanagar ($15.35 \%)$ followed by Mysore (-9.97\%),
Bangalore Rural (-8.31\%), Tumkur (-5.32\%) and Kolar (-4.38\%). Similar pattern of negative growth in production was observed in these districts. On the contrary to this, the growth rate in area and production was increasing in Ramanagara, Mandya and Chikkaballapur districts. Positive growth in Chikkaballapur, Ramanagara and Mandya districts could be due to introduction of Victory-1 high yielding mulberry variety (6500 kg/acre), which is exclusively grown on large scale area in these districts. Another reason might be maximum number of reeler's in these districts and existence of experienced farmers and these districts are newly formed carving from Kolar and Bangalore Rural.

However mixed trend of growth in productivity was observed in the traditional mulberry cultivating districts. The extent of growth in productivity was negative in Ramanagara (-4.98\%), Chamarajnagar ($3.51 \%)$, Kolar $(-0.75 \%)$ and Bangalore Rural $(-0.63 \%)$. The negative growth trend in Ramanagara, Chamarajnagar, Kolar and Bangalore rural might be due to scarcity of water resultant lower use of inputs. While it was positive in Mysore (3.24\%), Mandya (2.62\%), Tumkur (2.47\%) and Chikkaballapur $(1.47 \%)$. Thus, it can be concluded that growth trend of productivity in traditional districts was positive and significant.

The traditional districts as a whole growth in area $(1.77 \%)$ was negative and productivity $(1.36 \%)$ was positive as a resulted marginal decline in production $(-0.07 \%)$. It is mainly due to significant negative growth in area $(1.77 \%)$ even though the growth in productivity (1.36\%) was positively significant. The decline in area under mulberry in traditional sericulture producing districts might be due to severe scarcity of irrigation water during summer due to depletion of ground water and also drought situation prevailing in recent years. The 
another reason might be high volatility of the cocoon price resulted lesser profitability from sericulture enterprise which has discouraged large and medium farmers to shift from sericulture industry to other competing enterprise viz. horticulture and dairy farming. The location of these districts nearer to Bangalore city influenced on labour wage, hence workers are moving to Bangalore for earning better wage rate, resulted scarcity of labour and decline in area under mulberry.

Another reason could be urbanization, which resulted in conversion of agricultural lands to non-agricultural use due to higher price offered by real estate developers.

Non-traditional area
It is important to note that growth in area, production and productivity during study period were positive in all the districts of North Eastern Karnataka region, except area in Kalaburagi district. Whereas, other districts of non-traditional mulberry cultivating areas have shown mixed trend of positive as well as negative growth in area, production and productivity of mulberry silkworm cocoon.

Thus, the growth for area and production in non-traditional districts was found to be negative. Further, positive growth rate in productivity has ultimately resulted marginal positive growth rate in production of mulberry silkworm cocoon.

Table.1 Share of mulberry and silkworm cocoon production districts in the state total production

\begin{tabular}{|c|c|c|c|c|}
\hline $\begin{array}{c}\text { SI. } \\
\text { No }\end{array}$ & Districts & $\begin{array}{c}\text { Area under } \\
\text { mulberry (Ha) }\end{array}$ & $\begin{array}{c}\text { Cocoon } \\
\text { production (MT) }\end{array}$ & $\begin{array}{c}\text { Cocoon } \\
\text { productivity } \\
\text { (Kg/ ha) }\end{array}$ \\
\hline I & Traditional districts & 86081 & 60956 & 642 \\
\hline II & Non-traditional districts & $(87.72)$ & $(91.21)$ & \\
\hline a. & NEK districts & 3499 & 1392 & $445^{*}$ \\
\hline b. & Other districts & $(3.56)$ & $(2.08)$ & 407 \\
\hline & Total & $(8556$ & 4485 & $(6.71)$ \\
\hline
\end{tabular}

Note: $1 . *$ = Bivoltine variety

2. Figures in parenthesis indicate per cent to respective total

Table.2 Growth in area under mulberry and production and productivity of silkworm cocoon (1998-2017)

\begin{tabular}{|c|c|c|c|c|}
\hline SI. No. & Particulars & Area & Production & Prod cent/annum) \\
\hline $\mathbf{1}$ & NEK region & $4.44^{*}$ & $3.57^{*}$ & -0.24 \\
\hline $\mathbf{2}$ & Karnataka & $-1.74^{* *}$ & $-0.08^{*}$ & $1.55^{* *}$ \\
\hline $\mathbf{3}$ & India & -0.37 & $4.07^{*}$ & $4.47^{*}$ \\
\hline
\end{tabular}

Note: $*$ Significant at $1 \%$ level

$* *=$ Significant at $5 \%$ level

$* * *=$ Significant at $10 \%$ level 
Table.3 Growth in area under mulberry, production and productivity of silkworm cocoon in traditional and non-traditional areas of Karnataka (1998-2017)

(Per cent)

\begin{tabular}{|c|c|c|c|c|}
\hline $\begin{array}{l}\text { SI. } \\
\text { No. }\end{array}$ & District & Mulberry area & $\begin{array}{c}\text { Cocoon } \\
\text { production }\end{array}$ & $\begin{array}{c}\text { Cocoon } \\
\text { productivity }\end{array}$ \\
\hline I & \multicolumn{4}{|c|}{ Traditional areas } \\
\hline 1. & Bangalore Rural & $-8.31 *$ & $-8.89 *$ & -0.63 \\
\hline 2. & Chamarajnagar & $-15.35 *$ & $-18.33 *$ & $-3.51 * * *$ \\
\hline 3. & Chikkaballapura & 1.94 & 3.44 & 1.47 \\
\hline 4. & Kolar & $-4.38 *$ & $-5.09 *$ & -0.75 \\
\hline 5. & Mandya & $2.71 *$ & $5.41 *$ & $2.62 *$ \\
\hline 6. & Mysore & $-9.97 *$ & $-7.05 *$ & $3.24 *$ \\
\hline 7. & Tumkur & $-8.2 *$ & $-5.94 *$ & $2.47 *$ \\
\hline \multirow[t]{2}{*}{8.} & Ramanagara & 7.89 & 2.52 & $-4.98 *$ \\
\hline & Total & $-1.77 * *$ & -0.07 & $1.36^{*}$ \\
\hline II & \multicolumn{4}{|c|}{ Non-traditional areas } \\
\hline 1. & Ballari & $3.44 *$ & $3.19 *$ & -0.24 \\
\hline 2. & Bidar & $6.26^{*}$ & $9.19 *$ & 2.72 \\
\hline 3. & Kalaburagi & -0.34 & 0.92 & $1.27 * *$ \\
\hline 4. & Koppal & $3.86^{*}$ & $5.06 *$ & 1.14 \\
\hline 5. & Raichur & $5.08 *$ & $10.59 *$ & $5.24 *$ \\
\hline 6. & Yadgiri & 0.39 & 1.91 & 1.51 \\
\hline 7. & Bagalkot & $3.61 *$ & $6.22 *$ & $2.51 *$ \\
\hline 8. & Bengaluru Urban & $-4.9 *$ & $-2.46^{*}$ & $2.55^{*}$ \\
\hline 9. & Belagavi & -0.38 & 1.48 & $1.86^{*}$ \\
\hline 10. & Vijayapura & 0.35 & -0.35 & -0.70 \\
\hline 11. & Chikkamagaluru & $-5.85 *$ & $-7.5^{*}$ & -1.74 \\
\hline 12. & Chitradurga & $-5.38 *$ & $-6.10 *$ & -0.75 \\
\hline 13. & Dakshina Kannada & $-11.9 *$ & $-16.17 *$ & $-4.85 * *$ \\
\hline 14. & Davanagere & 0.67 & $2.73 *$ & $2.04 *$ \\
\hline 15. & Dharwad & $-2.96 * *$ & -1.60 & $1.40 * * *$ \\
\hline 16. & Gadag & $3.15^{*}$ & $9.44 *$ & $6.09 *$ \\
\hline 17. & Hassan & $-4.45^{*}$ & -2.64 & 1.89 \\
\hline 18. & Haveri & $9.49 *$ & $15.96 *$ & $5.90 *$ \\
\hline 19. & Kodagu & $-16.84 *$ & $-12.72 *$ & $4.96 * * *$ \\
\hline 20. & Shivamogga & -0.14 & $2.46 *$ & $2.61 * *$ \\
\hline 21. & Udupi & $-9.58 *$ & $-12.26^{*}$ & -2.97 \\
\hline \multirow[t]{2}{*}{22.} & Uttara Kannada & $-2.98 *$ & $-4.26^{*}$ & -1.32 \\
\hline & Total & $-1.48 * *$ & -0.56 & $1.71 *$ \\
\hline
\end{tabular}


Table.4 Constraints of farmers in mulberry cultivation and silkworm cocoon production

\begin{tabular}{|c|c|c|c|c|c|c|c|c|c|}
\hline \multirow{2}{*}{$\begin{array}{l}\text { SI. } \\
\text { No. }\end{array}$} & \multirow[t]{2}{*}{ Particulars } & \multicolumn{2}{|c|}{ Ballari } & \multicolumn{2}{|c|}{ Kalaburagi } & \multicolumn{2}{|c|}{ Raichur } & \multicolumn{2}{|c|}{ Overall } \\
\hline & & Score & Rank & Score & Rank & Score & Rank & Score & Rank \\
\hline I. & \multicolumn{9}{|c|}{ Mulberry cultivation } \\
\hline 1. & Irrigation problem in summer & 75 & I & 75 & I & 77 & I & 86 & I \\
\hline 2. & $\begin{array}{l}\text { Scarcity of labour with higher } \\
\text { wage rate }\end{array}$ & 73 & III & 76 & II & 76 & II & 85 & II \\
\hline 3. & Costly inputs & 70 & II & 71 & IV & 71 & III & 82 & III \\
\hline 4. & $\begin{array}{l}\text { Non availability of good } \\
\text { quality saplings }\end{array}$ & 72 & IV & 66 & III & 69 & $\mathrm{~V}$ & 81 & IV \\
\hline 5. & Soil is not suitable & 67 & $\mathrm{~V}$ & 70 & $\mathrm{~V}$ & 65 & IV & 80 & $\mathrm{~V}$ \\
\hline 6. & Un favorable climate & 66 & VI & 65 & VI & 66 & VI & 79 & VI \\
\hline II. & \multicolumn{9}{|c|}{ Cocoon production } \\
\hline 1. & $\begin{array}{l}\text { High temperature during } \\
\text { summer }\end{array}$ & 82 & I & 78 & I & 81 & I & 88 & I \\
\hline 2. & Lack of skilled labour & 74 & II & 76 & II & 78 & II & 85 & II \\
\hline 3. & Difficulty in obtaining DFLs & 69 & $\mathrm{~V}$ & 71 & III & 67 & IV & 82 & III \\
\hline 4. & $\begin{array}{l}\text { Non availability of inputs in } \\
\text { time }\end{array}$ & 71 & III & 68 & $\mathrm{~V}$ & 70 & III & 81 & IV \\
\hline 5. & High incidence of uji fly & 70 & IV & 69 & IV & 66 & $\mathrm{~V}$ & 80 & $\mathrm{~V}$ \\
\hline 6. & $\begin{array}{l}\text { High cost of silkworm rearing } \\
\text { equipment's }\end{array}$ & 64 & VI & 65 & VI & 64 & VI & 78 & VI \\
\hline III. & \multicolumn{9}{|c|}{ Marketing of cocoons } \\
\hline 1. & Fluctuating prices & 76 & I & 73 & I & 72 & II & 85 & I \\
\hline 2. & $\begin{array}{l}\text { Reeler's participation in the } \\
\text { market was less }\end{array}$ & 75 & II & 71 & II & 73 & I & 83 & II \\
\hline 3. & $\begin{array}{l}\text { Non-existence of market } \\
\text { facility }\end{array}$ & 71 & III & 68 & V & 69 & IV & 82 & III \\
\hline 4. & $\begin{array}{l}\text { Price received are not } \\
\text { remunerative }\end{array}$ & 66 & $\mathrm{~V}$ & 70 & III & 70 & III & 81 & IV \\
\hline 5. & $\begin{array}{l}\text { Unauthorized charges paid in } \\
\text { marketing }\end{array}$ & 68 & IV & 64 & VII & 67 & $\mathrm{~V}$ & 80 & $\mathrm{~V}$ \\
\hline 6. & Too many intermediaries & 63 & VII & 69 & IV & 66 & VI & 79 & VI \\
\hline 7. & $\begin{array}{l}\text { Lack of storage/ warehousing } \\
\text { facility }\end{array}$ & 65 & VI & 66 & VI & 65 & VII & 78 & VII \\
\hline
\end{tabular}

The extent of growth in non-traditional districts of mulberry cultivation indicated growth rate in area $(-1.48 \%)$ and production ($0.56 \%$ ) were negative while it was positive in case of productivity $(1.71 \%)$ of silkworm cocoon. This resulted meager decline in growth of cocoon production.
Constraints in production and marketing of mulberry and cocoon

The details of ranks for various mulberry cultivation constraints opined by the respondents in Ballari, Kalaburagi and Raichur were discussed below. The scarcity of water in mulberry cultivation during summer 
for irrigation of the crop (I-rank) tops the list among the cultivation constraints. Scarcity of labour with high wage rate (II-rank) was another constraint in mulberry cultivation. The other major constraints opined by respondents were, costly inputs (III-rank), Non availability of good quality saplings (IV-rank), unsuitable soil type (V-rank) and unfavorable climate (VI-rank) during summer (Table 4).

The farmers in study area expressed scarcity of irrigation water during summer season (over all Garrett score 86) and were most important major constraint in mulberry cultivation which in turn reduced mulberry yield with a corresponding reduction in number of DFLs reared. The mulberry crop for better yield should be regularly irrigated.

Besides, it is very much necessary to regulate the water supply to the crop carefully when the leaves are harvested during silkworm rearing. The reduced growths of leaves during rearing period affect the yield and quality from the point of cocoon production. Open wells and bore wells were the only sources of irrigation water for mulberry cultivation in the study area. Wells possessed limited supplies of water which were almost dried-up during summer. Further, rainfall is scanty and whatever is received is unevenly distributed. Hence, the regular irrigation is most critical for efficient production. Although the soils and climatic conditions of the area are ideally suited for extensive cultivation of mulberry, the availability of irrigation water largely influenced to restrict the area under mulberry.

Farmers also expressed that the scarcity of labour with high wage rate (over all Garrett score 82) was another major problem. Skilled labour is required for planting of mulberry cuttings and other operations. The respondents also reported that the inputs are costly such as cost of fertilizers, growth regulators, irrigation water and labour requirement, as prominent problem in the study area. However, other problems like non-availability of good quality mulberry cuttings followed by unsuitable soil type, and un-favourable climate were affecting quality of mulberry bio-mass production.

The majority (over all Garrett score 88) of respondents felt that high temperature during summer was the major constraint in case of cocoon production. It affected the health of silkworms there by the yield of cocoons. The farmers also felt that due to the lack of skilled labour (over all Garrett score 85) it was difficult to carry out the sericultural operations as silkworm rearing is a labour intensive enterprise and labour should be skilful in carrying out rearing activities. They also felt that difficulty in obtaining disease free laying (over all Garrett score 82). The respondents also opined that non-availability of inputs in time at every stage is difficult task to carry out cocoon rearing activities. Though the uji fly net was used by majority respondents, due to high incidence of uji fly the yield of cocoons was affected causing significant decline in the yield. The equipment's viz. rearing stands, trays, mountages, etc., are costly hence it was difficult to access these equipment's. The findings of the study are in line with the study conducted by Anil Kumar Yadav (2008).

The volatility of cocoon price, less number of reeler's participation in the auction, lack of local market facility were the major constraints in marketing of cocoon. The poor market facilities in Kalaburagi market forced farmers to sale their produce in Ramanagara market, which is far away from these study districts resulted higher transportation cost as opined by the farmers during survey. It is important to mention that very less number of reeler's participating in Kalaburagi and are deciding price themselves before auction takes place. This has resulted unauthorised deduction and delay in settlement of payments as expressed by majority of respondents of 
Kalaburagi district farmers. Hence, Kalaburagi market should be developed on far with Ramanagara market with better infrastructure facility in the market. Which will help to generate employment through concentration of large number of reeler's in the study area.

Traditional districts accounted for 87.72 per cent of Karnataka mulberry area and growth in area $(1.77 \%)$ was negative while productivity $(1.36 \%)$ was positive resulted marginal decline in production $(-0.07 \%)$. The extent of growth in non-traditional districts of mulberry cultivation indicated negative growth in area ($1.48 \%)$ and production $(-0.56 \%)$. The declining trend of growth in area under mulberry across the districts, state and at national level affected production of silkworm cocoon. Since, the net profit earned in sericulture farming and labour employment throughout the year is highly encouraging. Therefore there is a need for formulation of area stabilizing policy for encouraging sericulture farming.

\section{References}

Anil Kumar Yadav, 2008. Yield gaps and constraints in cocoon production in Karnataka: an econometric analysis. M. Sc. (Agri.) Thesis, Univ. of Agric. Sci., Dharwad, Karnataka (India).

Khan, L.A., 2009. State's top position in silk production under threat. The Hindu, 132 (57):P.4.

Sharad Bhatnagar and Shekhar Bhatnagar, 2008. The status of silk production in India. Agric. Situ. India, 66(1): 15-17.

Srinivasan, S. M., 2006. Performance of Indian Silk Industry under WTO Regime - An Econometric Analysis, M. Sc. (Agri.) Thesis, Uni. of Agri. Sci., Bangalore (Karnataka).

Vishakanta, 2018. An economic analysis of area, production and productivity of sericulture in India and Karnataka. Int. J. of Research in Applied Science \& Engineering Technology (IJRASET), 45(6): 3266-3272.

\section{How to cite this article:}

Anil Kumar, G.N., B.S. Reddy, S.B. Goudappa, G.M. Hiremath and Suresh S. Patil. 2019. Growth Performance of Silkworm Cocoon Production in Karnataka, India. Int.J.Curr.Microbiol.App.Sci. 8(11): 674-682. doi: https://doi.org/10.20546/ijcmas.2019.811.081 